\title{
Investigation of the Effect of Temperature Coefficients on Mono-Crystalline Silicon PV Module Installed in Kumasi, Ghana
}

\author{
Gabriel Takyi1,2, Frank Kwabena Nyarko, ${ }^{1,2}$ \\ ${ }^{1}$ Department of Mechanical Engineering, Kwame Nkrumah University of Science and Technology, Kumasi, Ghana \\ ${ }^{2}$ The Brew-Hammond Energy Centre, KNUST, Kumasi, Ghana \\ Email: gabrieltakyi@yahoo.co.uk,gtakyi.soe@knust.edu.gh
}

How to cite this paper: Takyi, G. and Nyarko, F.K. (2020) Investigation of the Effect of Temperature Coefficients on Mono-Crystalline Silicon PV Module Installed in Kumasi, Ghana. Journal of Power and Energy Engineering, 8, 20-34. https://doi.org/10.4236/jpee.2020.89003

Received: July 18, 2020

Accepted: September 18, 2020

Published: September 21, 2020

Copyright ( 2020 by author(s) and Scientific Research Publishing Inc. This work is licensed under the Creative Commons Attribution International License (CC BY 4.0).

http://creativecommons.org/licenses/by/4.0/

(c) (i) Open Access

\begin{abstract}
The performance of solar PV modules is significantly affected by temperature. This paper focuses on the determination of the effect of temperature on a commercial mono-crystalline silicon PV module whose temperature coefficients were not provided by the manufacturer for installation in Kumasi, Ghana, Sub-Saharan Africa (SSA) ambient. In order to determine the effect of temperature on the output characteristics of the module, the temperature coefficients of current, voltage and power were determined. First of all, the module was cooled to a temperature between $10^{\circ} \mathrm{C}-15^{\circ} \mathrm{C}$ in a cooling chamber, covered with cardboard paper before the outdoor electrical tests using Daystar I-V Curve tracer. The results show that as temperature increases, irradiance decreases significantly leading to a decrease in output power $\left(P_{\max }\right)$. The open circuit voltage $\left(V_{o c}\right)$ also decreases, whilst short circuit current $\left(I_{s c}\right)$ increases slightly. The temperature coefficients were obtained from the slopes of the plots of temperature against $P_{\max }, I_{s c}$ and $V_{o c}$ The slopes were used to determine how the respective output characteristics are affected as the module's temperature rises. The temperature coefficients for power, voltage and current were obtained from the slopes of the graphs using the IVPC software and found to be $-0.313 \mathrm{~W} /{ }^{\circ} \mathrm{C},-0.11 \mathrm{~V} /{ }^{\circ} \mathrm{C}$ and $0.004 \mathrm{~A} /{ }^{\circ} \mathrm{C}$ respectively. The results indicate that output power is a decreasing function of temperature (that is power decreases when temperature increases). This information will be useful to system developers, manufacturers and investors seeking to procure PV modules for installation in Kumasi, Ghana. The temperature coefficients of commercial PV modules could be independently verified using the technique employed in this study. Future work will focus on the long-term
\end{abstract}


effect of temperature on the electrical performance characteristics.

\section{Keywords}

Photovoltaics, Measurement, Irradiance, Temperature Coefficient, Sub-Saharan Africa

\section{Introduction}

The main limiting factor of PV systems is the low conversion efficiency of PV panels, which is strongly influenced by their operating temperatures [1]. Although the use of solar PV for energy generation is cheap and harmless to the environment since there are no emissions, its application comes with a number of drawbacks. In the rainy season for example, its efficiency is greatly decreased due to the decrease in the amount of irradiance the solar PVs receive. Additionally, although it makes use of the sun's energy to produce electricity, it is ironically greatly affected by high temperatures. When the temperature of a solar PV module increases above the temperature at STC $\left(25^{\circ} \mathrm{C}\right)$, its efficiency begins to greatly decrease. Two factors that affect solar PV efficiency are irradiance and temperature which are the main focus of this study. Out of the total radiation falling onto a PV panel, only up to $20 \%$ of the incident solar energy is converted to electricity. The rest is converted to heat. As a result, the accumulated heat energy causes an increase in the PV panel operating temperature, leading to a reduction in its electrical efficiency [2]. Under STC conditions (Irradiance of $1000 \mathrm{~W} / \mathrm{m}^{2}$, air mass of 1.5 and a temperature of $25^{\circ} \mathrm{C}$ ), the conversion efficiency of the PV panel is reported to decrease by about $0.40 \%-0.50 \%$ for each degree rise in temperature [3].

The measure of how solar PV's power, current, and voltage vary per degree change in temperature is determined by the temperature coefficient. The temperature coefficients of solar PVs are determined at standard test conditions. Solar PV modules are usually mounted on roofs which can usually reach temperatures of $70^{\circ} \mathrm{C}$. This poses serious problems for power generation as the total power output reduces with higher temperatures. Solar irradiance, which is the power per unit area received from the sun in the form of electromagnetic radiation in the wavelength range of the measuring instrument, also has a direct effect on solar panel power generation. A low solar radiation leads to lower power generation. The effect of temperature on output power from different types of PV panel has been observed by Dash et al. [4]. By referring to the temperature coefficient of PV panel, monocrystalline experienced the highest losses in output power with average of $-0.45 \% /{ }^{\circ} \mathrm{C}$. In a study conducted to determine the effect of temperature on PV parameters, it was concluded that the temperature coefficient of the open circuit voltage $\left(V_{o c}\right)$, power $\left(P_{\max }\right)$ and fill factor $(\mathrm{FF})$ were negative while that for the short circuit current $\left(I_{s c}\right)$ was positive [5]. Temperature coefficient is a coefficient expressing the relationship between a change in a 
physical property and the change in temperature that causes it. A negative temperature coefficient of power means that when the temperature rises and solar panels heat up, the power output of the solar panel decreases. The rated capacity, or power, of a solar panel (e.g. $250 \mathrm{Wp}$ ) is measured at $25^{\circ} \mathrm{C}$. The effect of temperature on the solar panel's power is measured by its thermal coefficient, expressed as $\% / \mathrm{K}$ or $\% /{ }^{\circ} \mathrm{C}$. It denotes the $\%$ change in power for 1-degree change in Kelvin or Celsius (both are the same on a unit level) above $25^{\circ} \mathrm{C}$. A negative (-) sign indicates the direction of the change. A temperature coefficient of $-0.45 \%{ }^{\circ} \mathrm{C}$ indicates that every $1{ }^{\circ} \mathrm{C}$ increase in temperature over $25^{\circ} \mathrm{C}$ will cause a $0.447 \%$ decrease in power. Equally, every $1^{\circ} \mathrm{C}$ decrease in temperature over $25^{\circ} \mathrm{C}$ will cause a $0.447 \%$ increase in power [6]. Each solar cell technology comes with unique temperature coefficients. These temperature coefficients are important and the temperature of the solar cell has direct influence on the power output of a solar PV module [7].

Crystalline solar cells are the dominant cell technology and usually come with a temperature coefficient of the maximum output power of about $-0.5 \% /{ }^{\circ} \mathrm{C}$. The rated power as generally indicated on the module's label is measured at $25^{\circ} \mathrm{C}$ and with any temperature increase above $25^{\circ} \mathrm{C}$ you have to consider power losses of $1 \%$ for every $2^{\circ} \mathrm{C}$ increase. Most installed solar modules in sunny countries easily reach higher temperatures than $25^{\circ} \mathrm{C}$. In fact, temperatures of $50^{\circ} \mathrm{C}$ and above are easily reached. Besides the temperature coefficient of $P_{\max }$ there are also other temperature coefficient ratings for solar PV modules. These are: temperature coefficient of the open circuit voltage $\left(V_{o c}\right)$, which measures the changing open circuit voltage values of the PV module when the temperature increases (or decreases). The temperature coefficient for voltage is negative meaning that voltage decreases per each degree rise in temperature. Temperature Coefficient of the short circuit current $\left(I_{s c}\right)$, which measures the changing short-circuit current values of the PV module when the solar cell temperature increases (or decreases). The temperature coefficient for current is positive meaning that current increases per each degree rise in temperature [8].

Different types of PV panel technology play different roles in generating output power caused by their sensitivity to the operating temperature. Suwapaet et al. indicated that amorphous PV panel is most efficient than monocrystalline silicon when operated under high operating temperature conditions [9]. For instance, at solar irradiance of $600 \mathrm{~W} / \mathrm{m}^{2}$, the mono-crystalline silicon produced less power than amorphous silicon at the same panel temperature [6]. In the work reported in [1] investigation was conducted into the effects of operating temperature on mono-crystalline PV panel at Perlis, Malaysia. A selected model of PV panel was simulated using PVsyst software in order to evaluate its output performance. Outdoor experimental study was also carried out and analyzed to determine the electrical data using PROVA 200 during the sunniest day. The experimental results indicated that the standard test condition (STC) parameters did not represent the real operating conditions of PV panel for outdoor conditions and that the elevating of PV panel temperature contributed to the negative 
impact on output performance of the panel. Kamkird et al. [10] carried out investigation on temperature coefficient using three PV module technologies (amorphous silicon, poly crystalline silicon and heterojunction intrinsic thin layer (HIT) in Thailand. Outdoor data was recorded for two years (2008 and 2009) and analysed using linear regression. The results show that the temperature coefficients obtained from the experiment differ from that stated by the manufacturer and also the temperature coefficient of 2009 was higher than 2008. In this study, the temperature dependency of a commercial mono-crystalline PV module output performance as well as its temperature coefficients are investigated in Kumasi, Ghana in sub-Saharan Africa conditions.

\section{Method and Material}

In this study, data was collected by cooling a $50 \mathrm{~W}$ as-received commercial mono-crystalline PV module for which temperature coefficient was not provided to a temperature below the ambient temperature in a cooling chamber. An infrared thermometer was used to measure the temperature of the module until it read the temperature specified for the experiment $\left(10^{\circ} \mathrm{C}-15^{\circ} \mathrm{C}\right)$. The module was then covered with cardboard sheets and quickly taken outside for the I-V tests to be performed under outdoor conditions according to IEC 60904-1 Standard. The initial cooling of the PV module to a low temperature was done in order to trace and analyze different I-V curves within a wider temperature range. This enables temperature coefficients to be obtained at different temperatures from the I-V curves that are traced.

\section{CURVE TRACING}

The I-V curve tracing was done using DS-1000 IV-Curve tracer manufactured by DAYSTAR, USA in conjunction with a laptop computer that runs an IVPC software. The DS-1000 tracer obtains an I-V curve by varying the electrical impedance connected across the PV module output terminals. Varying the impedance from zero to infinity causes the module operating point to change from $I_{s c}$ to $V_{o c}$ The DS-1000 achieves this impedance change by connecting the module to a capacitive load. As the capacitor charges, the module moves through its operating range and displays a set of current and voltage values that form the I-V curve. The DS-1000 IV tracer traces the I-V curves by measuring, computing and analyzing the output electrical parameters of the PV modules. Typical module electrical parameters considered are:

Short-circuit current $\left(I_{s c}\right)$;

Open-circuit voltage $\left(V_{o c}\right)$;

Maximum power current $\left(I_{m p}\right)$;

Maximum power voltage $\left(V_{m p}\right)$;

Maximum power output $\left(P_{\max }\right)$;

Fill factor (FF).

THE CRITICAL CONSIDERATIONS

Description of Open-Circuit Voltage with the Single Diode Model

$\mathrm{I}-\mathrm{V}$ characteristic and the equivalent circuit with the suitable mathematical 
model are important tools to study and to determine the parameters of the photovoltaic cells in different conditions. There are three models that can be used to model the diode: one, two, and three-diode model function of the electric current conduction mechanism from the photovoltaic cell as the diffusion mechanism, the generation-recombination mechanism, and the thermionic mechanism [1]. The generally accepted model is the one-diode model [11]. The equivalent circuit for this model can be seen in Figure 1, and the model is described mathematically by Equation (1).

Open circuit voltage $\left(V_{o c}\right)$ is the maximum possible voltage from the PV cell with zero external current. It has typical values of $600 \mathrm{mV}$ for crystalline cells. $V_{o c}$ depends on the quality of the material (low values of $I_{o}$ ) and increases very slightly with irradiance. On the other hand, $V_{o c}$ is a strong function of temperature with a high negative temperature coefficient (Roughly $-0.35 \% /{ }^{\circ} \mathrm{C}$ or about $-2.2 \mathrm{mV} /{ }^{\circ} \mathrm{C}$ ). The reason for its strong dependence on temperature can be explained using Figure 1, where:

$I=$ Total external circuit current;

$I_{p h}=$ Photon current;

$I_{d}=$ Diode current;

$I_{R_{s h}}=$ Current passing through the shunt resistor;

$R_{S}=$ Current passing through the series resistor.

The external current $(I)$ through the load is given by

$$
I=I_{p h}-I_{d}-I_{s h}
$$

The equation governing the I-V characteristics of a PV model or cell is then given by

$$
I=I_{p h}-I_{o}\left[\mathrm{e}^{q V_{t} / a k T}-1\right]-\left(V-I R_{s}\right) / R_{s h}
$$

where,

$$
\begin{aligned}
& I_{o}=\text { Dark saturation current; } \\
& q=\text { Electric charge; } \\
& k=\text { Steffan Boltzmann's constant; } \\
& a=\text { Ideality factor; } \\
& V_{t}=\text { The thermal voltage; } \\
& T=\text { The temperature. }
\end{aligned}
$$

The short circuit current, $\left(I_{s c}\right)$ is given by setting $V$ in Equation (2) equal to

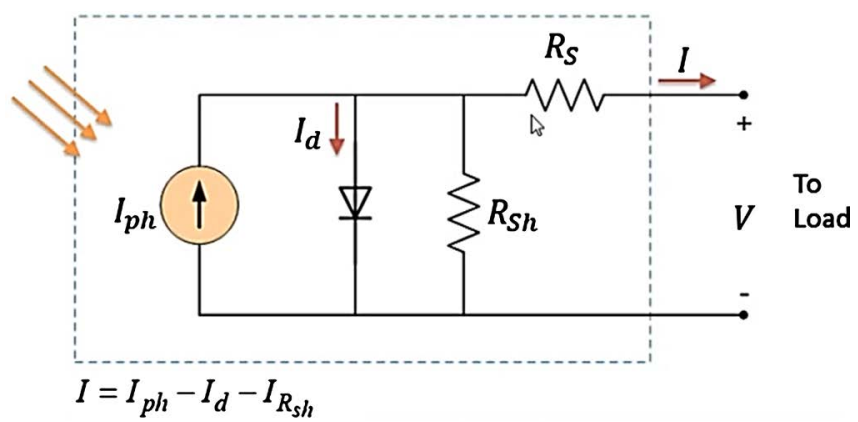

Figure 1. Single Diode Model of Solar PV Cell (E.L. Meyer 2017) [12]. 
zero and assuming that $R_{s}$ is negligibly small, thus

$$
I_{s c}=I_{p h}
$$

Similarly, the cell's $V_{o c}$ is obtained when no external current flows, that is $I=0$ in Equation (2).

Formula showing how $V_{o c}$ depends on temperature:

Assuming that $I_{o} \ll I_{s c}$ and $R_{s h} \gg V_{o c} / I_{s c}, V_{o c}$ is then given by

$$
V_{o c}=\frac{\alpha k T}{q} \ln \left(\frac{I_{p h}}{I_{o}}+1\right)
$$

The dark saturation current $I_{o}$, of the PV cell is strongly dependent on temperature. This dependence is governed by equation 5 [13], where $A$ is equal to $1.5 \times 10^{8} \mathrm{~mA} \cdot \mathrm{cm}^{-2}$, and $E_{g}$ is the band gap energy, $q$ is the electron charge (1.602 $\times 10^{-19}$ Coulomb), $k$ is Boltzmann's constant $\left(1.381 \times 10^{-23} \mathrm{~J} / \mathrm{K}\right)$ and $T$, the temperature.

$$
I_{o}=A \mathrm{e}^{-\left(q E_{g} / k T\right)}
$$

Equation (4) implies that ( $V_{o c}$ is inversely proportional to $I_{o}$-as shown in Equation (6).

$$
V_{o c} \propto \frac{1}{I_{o}}
$$

Therefore, as temperature increases, $I_{o}$ increases and as $I_{o}$ increases, $V_{o c}$ decreases [14].

The behavior of the photovoltaic cell parameter function of the temperature is very well described by the temperature coefficients [15] [16]. The temperature coefficients, (TC) can be absolute and normalized as in the following [17] [18],

$$
\begin{gathered}
T C_{a}(P)=\frac{\mathrm{d} P}{\mathrm{~d} T} \\
T C_{n}(P)=\left.\frac{1}{P} \frac{\mathrm{d} P}{\mathrm{~d} T}\right|_{T=25^{\circ} \mathrm{C}}
\end{gathered}
$$

Where, $P$ represents the parameter of the photovoltaic cell and $T$ is the temperature. The dependence of the photovoltaic cell parameter function of the temperature is approximately linear [16], and thus, the temperature coefficients of the parameters can be determined experimentally using the linear regression method [18]. The mechanisms which influence the performance of the photovoltaic cell can be better studied if the normalized temperature coefficient of the $P_{\max }$ is considered as a sum of the normalized temperature coefficients of the $I_{s c}$ $V_{o c}$ and FF [16].

\section{EFFECT OF TEMPERATURE ON THE PV CELL}

From Figure 2, it can be seen that as temperature increases, $I_{s c}$ increases very slightly and is almost negligible but a huge decrease can be seen in the $V_{o c}$. The most dominant effect of temperature is on the $V_{o c}$ with a temperature coefficient of about $-0.35 \% /{ }^{\circ} \mathrm{C}$ or about $-2.2 \mathrm{mV} /{ }^{\circ} \mathrm{C}$. On the other hand, $I_{s c}$ increases 


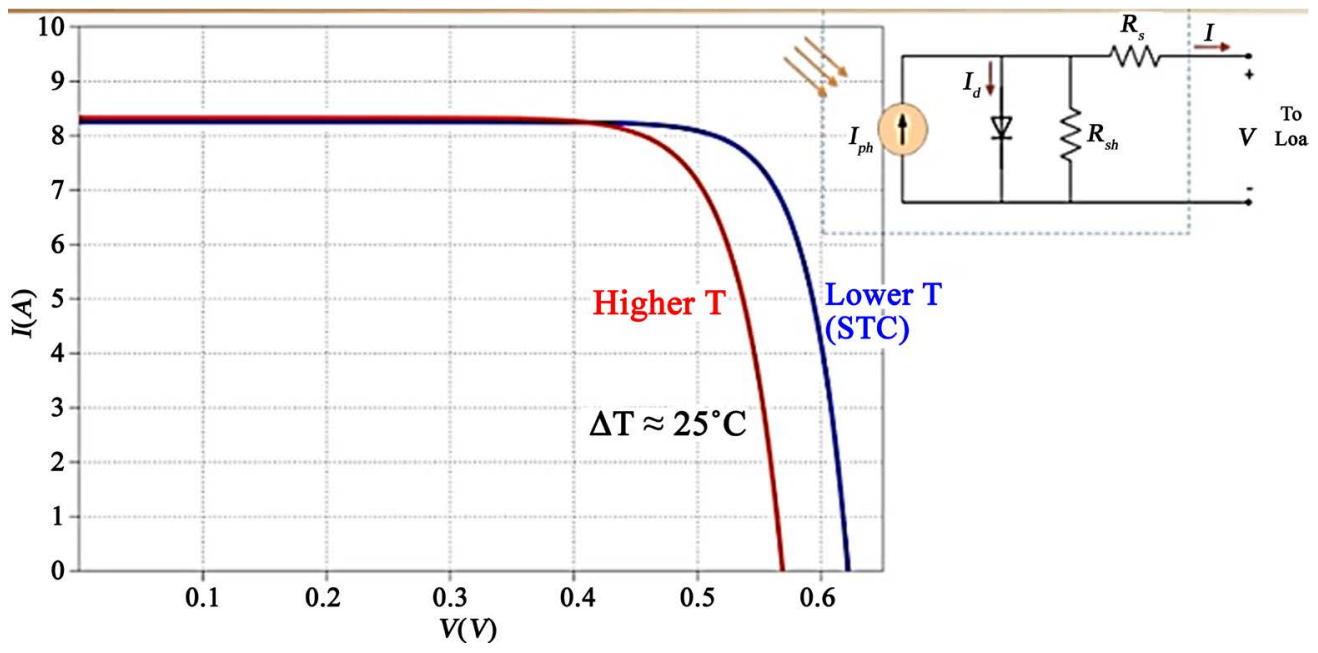

Figure 2. Variation of I-V characteristics with changing temperature.

slightly since the band gap of the material decreases slightly with the temperature and for a given electron-hole pair created $\left(0.05 \% /{ }^{\circ} \mathrm{C}\right)$. As can be seen from both the changing effects of temperature and irradiance, the maximum power is observed to be affected since the curve changes in response to changes in temperature and irradiance which affects the location of the knee where the maximum power produced is located [19] [20].

\section{Experimental}

This section outlines the experiments performed on the PV modules. The test site location (College of Engineering, KNUST, Kumasi, Ghana) is on latitude $6^{\circ} 40^{\prime \prime} \mathrm{N}$ and longitude $1^{\circ} 37^{\prime \prime} \mathrm{W}$, and elevation of $250 \mathrm{~m}$ above sea level. The tests were carried out in February on a bright day with a clear sky between the hours of 12:30 pm - 14:00 pm when the radiance is quite high.

\section{PV MODULE COOLING}

Data was collected (for $I_{s c}, V_{o c}$ and $P_{\max }$ ) by cooling the PV module to a temperature between $\left(10^{\circ} \mathrm{C}-15^{\circ} \mathrm{C}\right)$ in a cooling chamber. The module was then covered with cardboard sheets and quickly taken outside for twenty (20) I-V tests to be performed under outdoor conditions. The initial cooling of the PV module to a low temperature was done in order to trace and analyze different I-V curves within a wider temperature range. This enables temperature coefficients to be obtained at different temperatures from the I-V data. Figure 3 shows the experimental set-up for the I-V tests. It shows the mono-crystalline module position in the same plane as the reference cell, thermocouple placed at the back of the module to record the module temperature, the DAYSTAR I-V curve tracer and computer.

\section{Results and Analysis}

Table 1 and Table 2 show the nameplate ratings and raw data respectively obtained from the experiment. Figure 4 and Figure 5 show the plots for the raw 


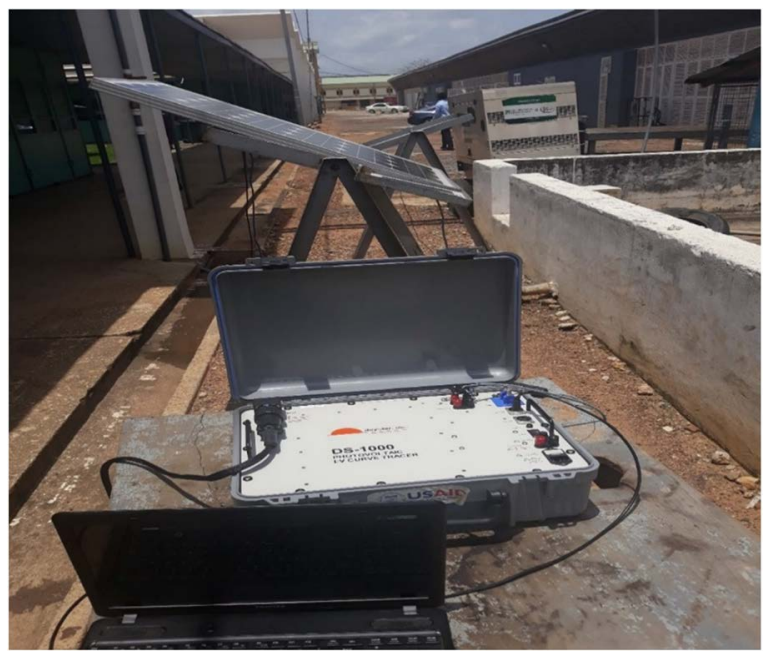

Figure 3. Photograph of experimental setup.

Table 1. Mono-crystalline silicon module name plate data.

\begin{tabular}{ccc}
\hline Maximum Power $\left(P_{\max }\right)$ & 50 & $\mathrm{~W}$ \\
Maximum Power Voltage $\left(V_{m p}\right)$ & 17.3 & $\mathrm{~V}$ \\
Maximum Power Current $\left(I_{m p}\right)$ & 2.89 & $\mathrm{~A}$ \\
Open Circuit Voltage $\left(V_{o c}\right)$ & 21.5 & $\mathrm{~V}$ \\
Short Circuit Current $\left(I_{s c}\right)$ & 3.2 & $\mathrm{~A}$ \\
Maximum System Voltage & 1000 & $\mathrm{~V}$ \\
Operating Temperature & $-40-80$ & ${ }^{\circ} \mathrm{C}$ \\
Dimension & $850 * 550 * 35$ & $\mathrm{Mm}$ \\
Net Weight & 5.8 & $\mathrm{Kg}$ \\
\hline
\end{tabular}

Table 2. IV raw data for mono-crystalline silicon module.

\begin{tabular}{ccccccc}
\hline $\begin{array}{c}\text { Output Power } \\
\left(P_{\max }\right)(\mathrm{W})\end{array}$ & $I_{s c}(\mathrm{~A})$ & $V_{o c}(\mathrm{~V})$ & $I_{\text {peak }}(\mathrm{A})$ & $V_{\text {peak }}(\mathrm{V})$ & $\begin{array}{c}\text { Irradiance } \\
\left(\mathrm{W} / \mathrm{m}^{2}\right)\end{array}$ & $\begin{array}{c}\text { Temperature } \\
\left({ }^{\circ} \mathrm{C}\right)\end{array}$ \\
\hline 48.1 & 2.91 & 21.8 & 2.66 & 18.1 & 906 & 29.7 \\
47.0 & 2.91 & 21.4 & 2.67 & 17.6 & 910 & 29.0 \\
46.4 & 2.93 & 21.1 & 2.68 & 17.3 & 893 & 31.0 \\
46.1 & 2.93 & 21.0 & 2.68 & 17.2 & 894 & 31.9 \\
45.8 & 2.93 & 20.9 & 2.68 & 17.1 & 894 & 32.7 \\
45.3 & 2.91 & 20.8 & 2.64 & 17.2 & 888 & 33.8 \\
44.9 & 2.89 & 20.7 & 2.63 & 17.0 & 883 & 34.6 \\
44.5 & 2.89 & 20.7 & 2.63 & 16.9 & 887 & 35.7 \\
44.2 & 2.89 & 20.6 & 2.63 & 16.9 & 881 & 36.5 \\
43.8 & 2.88 & 20.5 & 2.62 & 16.8 & 883 & 37.7 \\
43.7 & 2.89 & 20.4 & 2.61 & 16.7 & 878 & 38.5 \\
43.6 & 2.89 & 20.3 & 2.64 & 16.5 & 884 & 39.4 \\
\hline
\end{tabular}




\section{Continued}

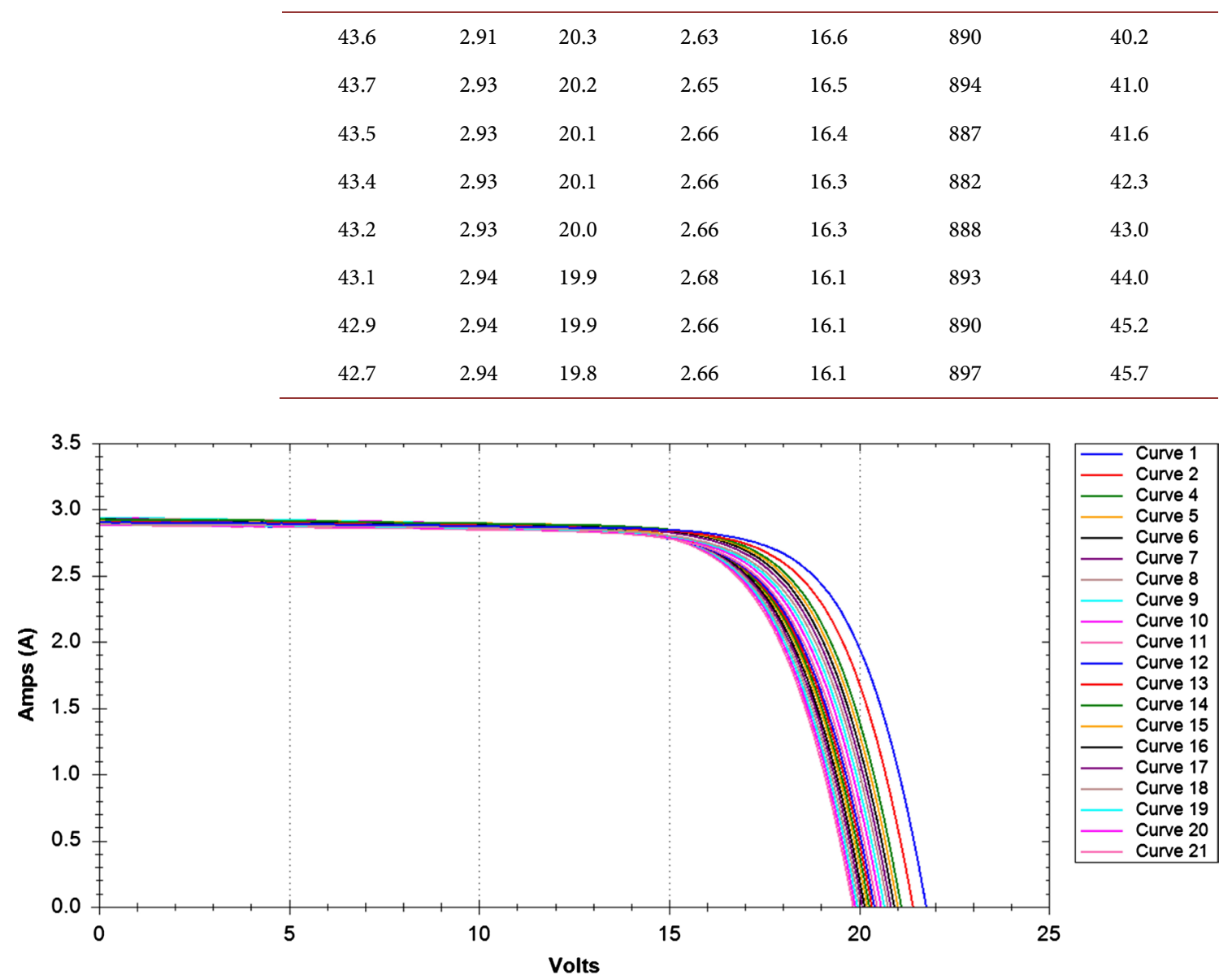

Figure 4. Multiplot of raw data for current versus voltage.
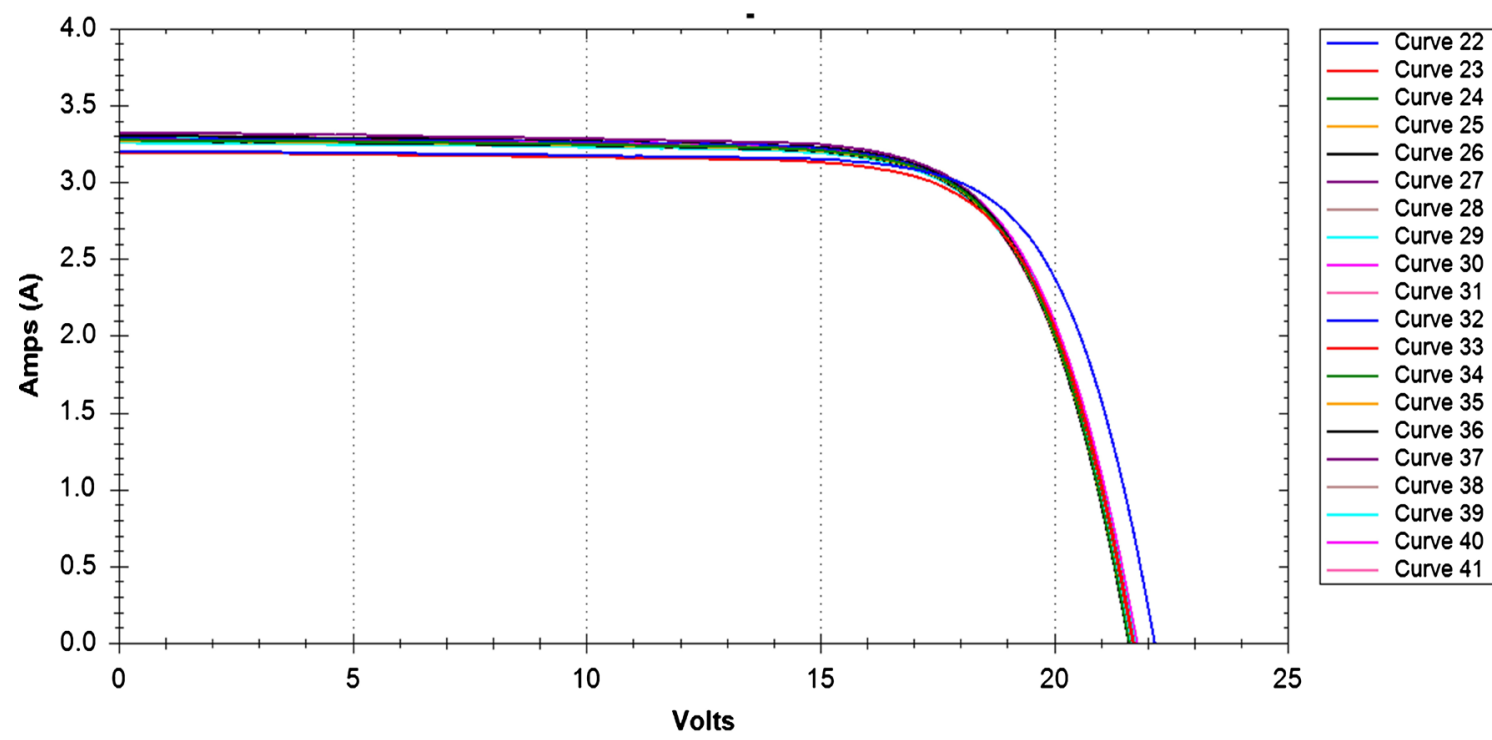

Figure 5. Multiplot of normalized current versus normalized voltage.

data and normalised data respectively. The plots show I-V curves with no evidence of shading. Table 2 shows the results (raw data) of the I-V tests of the ex- 
periment including the short-circuit current, $I_{s c}$ open-circuit voltage, $V_{o c}$ and the maximum power, $P_{\max }$. These are the parameters whose temperature coefficients are to be determined. To find the temperature coefficient of the above-mentioned parameters, graphs of power, short-circuit current and open-circuit voltage vs temperature are plotted. To find the temperature coefficient of current, for example, the gradient of the graph of $I_{s c}$ versus temperature is determined. This gradient corresponds to the rate at which the current varies with temperature and this is known as the temperature coefficient of current. In the same way, the gradients of the graphs of $V_{o c}$ versus temperature and $P_{\max }$ versus temperature are calculated. It is expected that the temperature coefficient of current will return a positive value since the current of the PV module increases slightly with increasing temperature. Both the temperature coefficient of voltage and the temperature coefficient of power will have negative gradients since increases in temperature has a greater effect on voltage and hence causes the voltage to drop thereby affecting the power produced. Table 2 also shows that when the temperature increases, $P_{\max }$ and $V_{o c}$ decrease significantly whilst $I_{s c}$ increases slightly. Figures 6-8 show the graphs of $P_{\max }, I_{s c}$ and $V_{o c}$ versus temperature. Table 3 shows the normalised data which shows higher values than the

Table 3. Normalized data for mono-crystalline silicon module.

\begin{tabular}{ccccccc}
\hline Power $(\mathrm{W})$ & $I_{s c}(\mathrm{~A})$ & $V_{o c}(\mathrm{~V})$ & $I_{\text {peak }}(\mathrm{A})$ & $V_{\text {peak }}(\mathrm{V})$ & $\begin{array}{c}\text { Irradiance } \\
\left(\mathrm{W} / \mathrm{m}^{2}\right)\end{array}$ & $\begin{array}{c}\text { Tempera- } \\
\text { ture }\left({ }^{\circ} \mathrm{C}\right)\end{array}$ \\
\hline 59.1 & 3.21 & 23.8 & 2.96 & 19.9 & 1000 & 25 \\
57.5 & 3.20 & 23.4 & 2.96 & 19.4 & 1000 & 25 \\
56.8 & 3.28 & 22.8 & 3.02 & 18.8 & 1000 & 25 \\
56.3 & 3.27 & 22.6 & 3.03 & 18.6 & 1000 & 25 \\
56.0 & 3.27 & 22.5 & 3.03 & 18.5 & 1000 & 25 \\
56.0 & 3.28 & 22.5 & 3.01 & 18.6 & 1000 & 25 \\
55.8 & 3.28 & 22.5 & 3.02 & 18.5 & 1000 & 25 \\
55.8 & 3.26 & 22.6 & 2.99 & 18.6 & 1000 & 25 \\
54.8 & 3.28 & 22.1 & 3.01 & 18.2 & 1000 & 25 \\
54.5 & 3.27 & 22.1 & 2.99 & 18.2 & 1000 & 25 \\
54.6 & 3.29 & 22.0 & 3.01 & 18.1 & 1000 & 25 \\
54.2 & 3.28 & 22.0 & 3.01 & 18.0 & 1000 & 25 \\
53.4 & 3.27 & 21.8 & 2.99 & 17.9 & 1000 & 25 \\
53.3 & 3.27 & 21.7 & 2.99 & 17.8 & 1000 & 25 \\
54.2 & 3.30 & 21.9 & 3.03 & 17.9 & 1000 & 25 \\
54.2 & 3.32 & 21.8 & 3.05 & 17.8 & 1000 & 25 \\
53.5 & 3.31 & 21.7 & 3.02 & 17.7 & 1000 & 25 \\
52.7 & 3.29 & 21.5 & 3.03 & 17.4 & 1000 & 25 \\
53.3 & 3.31 & 21.6 & 3.02 & 17.6 & 1000 & 25 \\
52.2 & 3.28 & 21.4 & 2.99 & 17.5 & 1000 & 25 \\
\hline & & & & & &
\end{tabular}


nameplate values and raw dada. The tolerances (typically $\pm 10 \%$ ) are not provided in the nameplate ratings and have therefore not been taken account of.

Figure 4 and Figure 5 show the multiplots of the IV raw data and normalised plots respectively.

\section{TEMPERATURE COEFFICIENT OF POWER}

To find the temperature coefficient of power, a graph of normalized power vs temperature was plotted as shown in Figure 6. As indicated in section 2.0, the dependence of the photovoltaic cell parameter function of the temperature is approximately linear and therefore, the temperature coefficients of the parameters can be determined experimentally using the linear regression method [19] and the normalized data.

From the graph, the resulting gradient will be a negative value due to the direction of the line of best fit. The temperature coefficient of power was calculated by finding the gradient of this line using the slope function in Microsoft Excel. The slope was then calculated and the temperature coefficient of power for the monocrystalline $\mathrm{PV}$ module was found to be $-0.312 \mathrm{~W} /{ }^{\circ} \mathrm{C}$. This means that for each degree rise of the module temperature above $25^{\circ} \mathrm{C}$, the module loses approximately $0.313 \mathrm{~W}$ of power.

\section{TEMPERATURE COEFFICIENTS OF VOLTAGE AND CURRENT}

Similarly, to find the temperature coefficients of voltage and current, graphs of normalized voltage and current vs temperature were plotted as shown in Figure 7 and Figure 8 respectively. The temperature coefficients for voltage and current obtained were $-0.112 \mathrm{~V} /{ }^{\circ} \mathrm{C}$ and $0.004 \mathrm{~A} /{ }^{\circ} \mathrm{C}$ respectively. This implies that per each degree rise above $25^{\circ} \mathrm{C}$, the module's voltage drops by $-0.112 \mathrm{~V}$ approximately whilst the current rises slightly by $0.003831199 \mathrm{~A}$.

EFFECT OF TEMPERATURE COEFFICIENT OF POWER ON SOLAR MODULE'S POWER PRODUCTION

To see how temperature coefficient affects power production of a solar PV module, the mono-crystalline module that was used in this study is taken into consideration. This module is rated at $50 \mathrm{~W}$ according to the nameplate rating (the tolerances were not indicated). From the experiment, a value of $-0.312 \mathrm{~W} /{ }^{\circ} \mathrm{C}$

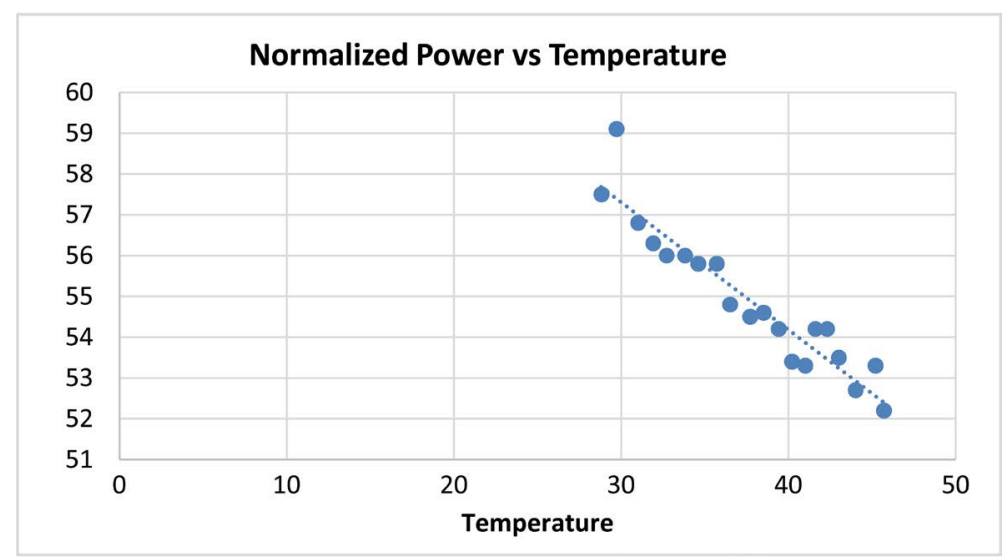

Figure 6. Plot of normalized power against temperature. 


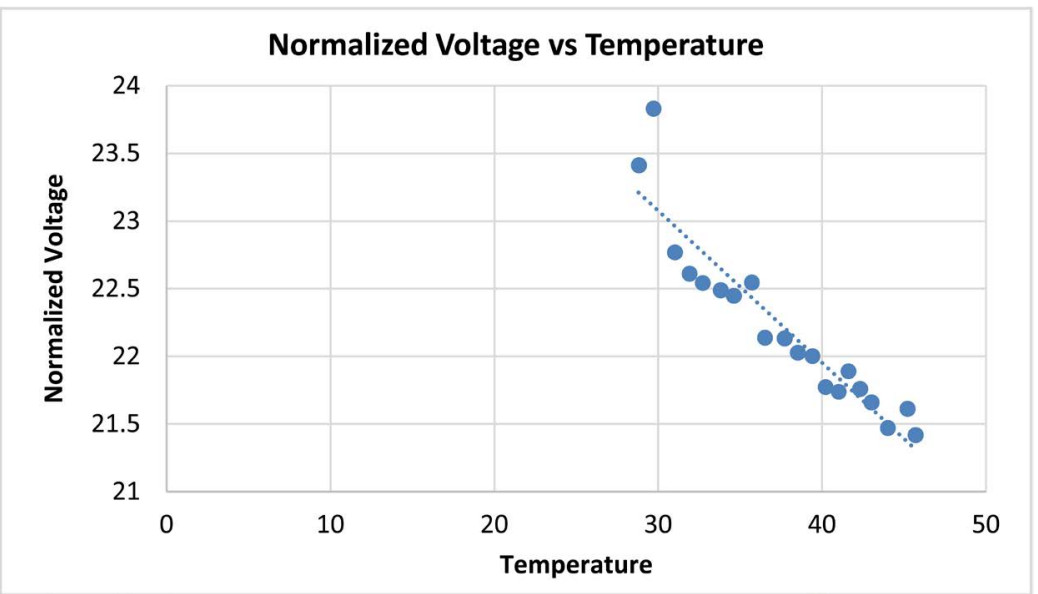

Figure 7. Plot of normalized voltage against temperature.

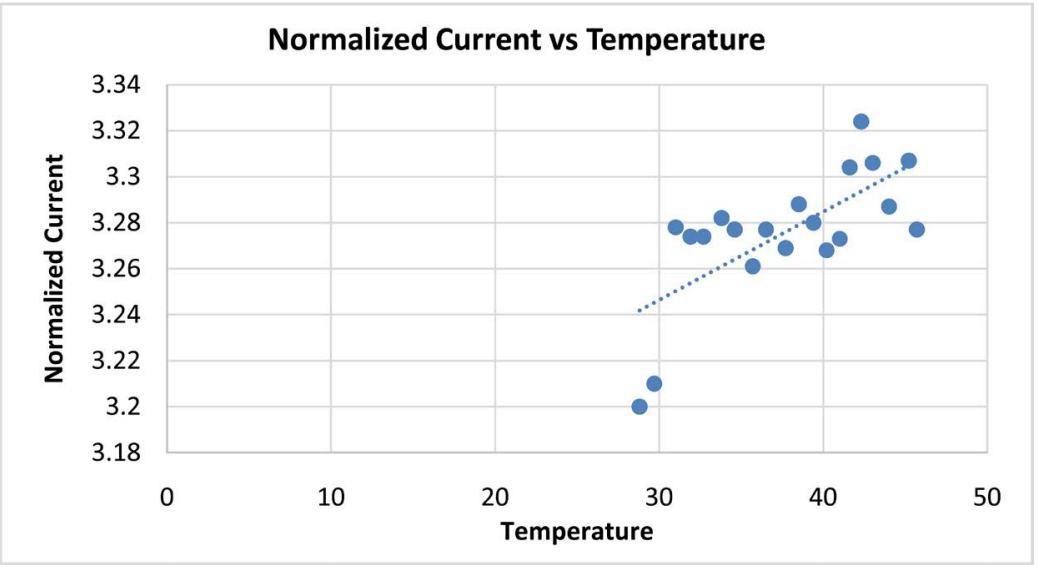

Figure 8. Plot of normalized current against temperature.

was obtained which means that the module loses $0.3125 \mathrm{~W}$ for each degree rise above $25^{\circ} \mathrm{C}$. This may seem insignificant for just one module since at $26^{\circ} \mathrm{C}$ the module will be producing $49.6875 \mathrm{~W}$ which is approximately $50 \mathrm{~W}$. Another scenario is considered where the module is operating around $55^{\circ} \mathrm{C}$. At this temperature, the module will lose $9.375 \mathrm{~W}(0.313 \times 30=9.4 \mathrm{~W})$. The actual power produced by this module at this temperature will be: $50 \mathrm{~W}-9.375 \mathrm{~W}=40.6 \mathrm{~W}$. This implies that at $55^{\circ} \mathrm{C}$, the panel loses almost $10 \mathrm{~W}$. This may still seem insignificant but single modules are hardly used unless they are for very small applications such as a street lighting. Houses, companies and large industries that use solar power use solar arrays which are a collection of solar modules. Assuming a solar power plant needs 100,000 mono-crystalline PV modules in order to satisfy a $5 \mathrm{MW}$ power demand, the full $5 \mathrm{MW}$ will not be achieved if the temperature coefficient is not taken into consideration. Considering the temperature coefficient that was obtained as $-0.31 \mathrm{~W}$ for the $50 \mathrm{~W}$ mono-crystalline module operating at $55^{\circ} \mathrm{C}$, the actual power the plant will produce is:

Power loss $=9.4 \mathrm{~W} \times 100,000$

Power loss $=937,500 \mathrm{~W}$ 
Actual Power Produced $=5,000,000 \mathrm{~W}-937,500 \mathrm{~W}$

Actual Power Produced $=4,062,500 \mathrm{~W} \approx 4.06 \mathrm{MW}$

This means that the array of 100,000 modules will not be enough to satisfy the $5 \mathrm{MW}$ demand since the array loses about $1 \mathrm{MW}$ as a result of the temperature coefficient of power of each model.

The temperature coefficient of power could possibly be ignored when sizing solar requirements on a very small scale (e.g. for a street light) but could have serious effects when sizing for large-scale applications.

\section{Conclusions}

In this study, the dependency of mono-crystalline photovoltaic module parameters with respect to temperature (under sub-Saharan Africa ambient) was investigated. The effects of environmental factors such as ambient temperature and solar irradiance on output power, voltage and current were also examined. The test vehicle used in this study was a commercial $50 \mathrm{~W}$ rated mono-crystalline PV module which was free from any form of load connection. The method employed involved cooling of the PV module, I-V curve characterization and performance analysis at standard test conditions and calculation of temperature coefficients. The following major conclusions are drawn:

The temperature of the mono-crystalline module has a significant effect on output power and voltage than on current. The results indicate that output power increases with increasing irradiance but decreases when temperature increases. The temperature coefficients for power, voltage and current which were not provided on the nameplate of the commercial PV module were determined as $-0.313 \mathrm{~W} /{ }^{\circ} \mathrm{C},-0.112 \mathrm{~V} /{ }^{\circ} \mathrm{C}$ and $0.004 \mathrm{~A} /{ }^{\circ} \mathrm{C}$ respectively through experimentation. The temperature coefficient of voltage and power for the mono-crystalline module were negative. It was observed that the temperature coefficient of current was positive and relatively smaller. This smaller value indicates that the output current increases just slightly with the increase in temperature of the modules. Knowledge of the temperature coefficients of different modules is key in selecting the appropriate photovoltaic module for a particular purpose at a particular site. This technique has provided a means of determining the temperature coefficient of a module whose temperature coefficients were not provided by the manufacturer. Knowledge of the temperature coefficients of different modules is key in selecting the appropriate photovoltaic module for a particular purpose at a particular site. Future work in this area will seek to investigate the long-term effect of temperature on different PV module technologies installed under SSA conditions.

\section{Acknowledgements}

The authors would like to acknowledge the financial support received from the USAID for the PRESSA Project Sub-Grant no. 2000004829 through the US National Academy of Sciences. The technical support provided by Dr. Mani and Sai 
Tatapudi of Arizona State University Photovoltaic Reliability Laboratory is greatly appreciated.

\section{Conflicts of Interest}

The authors declare no conflicts of interest regarding the publication of this paper.

\section{References}

[1] Amelia, A.R., Irwan, Y.M., Leow, W.Z., Irwanto, M., Safwati, I. and Zhafarina, M. (2016) Investigation of the Effect of Temperature on Photovoltaic (PV) Panel Output Performance. International Journal on Advanced Science Engineering, 6, 682-688. https://doi.org/10.18517/ijaseit.6.5.938

[2] Zhang, X., Shen, J., Xu, P., Zhao, X. and Xu, Y. (2014) Socio-Economic Performance of a Novel Solar Photovoltaic/Loop-Heat-Pipe Heat Pump Water Heating System in Three Different Climatic Regions. Energy, 135, 20-34. https://doi.org/10.1016/j.apenergy.2014.08.074

[3] Natarajan, S., Mallick, T., Katz, M. and Weingaertner, S. (2011) Numerical Investigations of Solar Cell Temperature for Photovoltaic Concentrator System with and without Passive Cooling Arrangements. International Journal of Thermal Sciences, 50, 2514-2521. https://doi.org/10.1016/j.ijthermalsci.2011.06.014

[4] Dash, P.K. and Gupta, N.C. (2015) Effect of Temperature on Power Output from Different Commercially Available Photovoltaic Modules. International Journal of Engineering Research and Applications, 5, 148-151.

[5] Indra, B.K. (2015) Effect of Temperature on the I-V Characteristics of a Polycrystalline Solar Cell. Journal of Nepal Physical Society, 3, 35-40.

https://doi.org/10.3126/jnphyssoc.v3i1.14440

[6] Temperature Coefficient of Solar Panels-Definition, Glossary, Details-Solar Mango-Solar Mango \# 1, Guide for Solar (2018).

http://www.solarmango.com/dictionary/temperature-coefficient

[7] King, D.L., Kratochvil, J.A. and Boyson, W.E. (1997) Temperature Coefficients for PV Modules and Arrays: Measurement Methods, Difficulties, and Results. Sandia National Laboratories, Albuquerque. 26th PVSC Conference, Anaheim, 3 September-3 Octo1997, 1183-1186.

[8] Niclas, D.W. (2018) Measuring the Temperature Coefficient of A PV Module. Sinovoltaics.

https://sinovoltaics.com/solar-basics/measuring-the-temperature-coefficients-of-apv-module

[9] Suwapaet, N. and Boonla, P. (2014) The Investigation of Produced Power Output during High Operating Temperature Occurrences of Monocrystalline and Amorphous Photovoltaic Modules. Energy Procedia, 52, 459-465. https://doi.org/10.1016/j.egypro.2014.07.098

[10] Kamkird, P., Ketjoy, N., Rakwichian, W. and Sukchai, S. (2011) Investigation on Temperature Coefficients of Three Types of Photovoltaic Module Technologies under Thailand Operating Condition. Procodia Engineering, 32, 376-383. https://doi.org/10.1016/j.proeng.2012.01.1282

[11] Cotfas, D.T., Cotfas, P.A. and Kaplanis, S. (2013) Methods to Determine the dc Parameters of Solar Cells: A Critical Review. Renewable and Sustainable Energy Reviews, 28, 588-596. https://doi.org/10.1016/j.rser.2013.08.017 
[12] Meyer, E. (2017) Extraction of Saturation Current and Ideality Factor from Measuring $V_{o c}$ and $I_{s c}$ of Photovoltaic Modules. International Journal of Photoenergy, 2017, Article ID: 8479487. https://doi.org/10.1155/2017/8479487

[13] Green, M.A. (1982) Solar Cell Operating Temperature Principles, Technology and System Applications Solar Energy, 28, 447. https://doi.org/10.1016/0038-092X(82)90265-1

[14] Ayyanar, R. (2014) PV I-V Characteristics Part $1 I_{s c} V_{o c}$ Arizona State University, Tempe. https://www.youtube.com/watch?v=xD5PG-WOUcU\&t=36s

[15] Chander, S., Purohit, A., Sharma, A., Arvind, Nehra, S.P. and Dhaka, M.S. (2015) A Study on Photovoltaic Parameters of Monocrystalline Silicon Solar Cell with Cell Temperature. Energy Reports, 1, 104-109. https://doi.org/10.1016/j.egyr.2015.03.004

[16] Dupre, O., Vaillon, R. and Green, M.A. (2016) Experimental Assessment of Temperature Coefficient Theories for Silicon Solar Cells. IEEE Journal of Photovoltaics, 6, 56-60. https://doi.org/10.1109/JPHOTOV.2015.2489864

[17] Singh, P. and Ravindra, N.M. (2012) Temperature Dependence of Solar Cell Performance-An Analysis. Solar Energy Materials and Solar Cells, 101, 36-45. https://doi.org/10.1016/j.solmat.2012.02.019

[18] Emery, K., Burdick, J. and Caiyem, Y. (1996) Temperature Dependence of Photovoltaic Cells, Modules and Systems. Conference Record of the Twenty Fifth IEEE Photovoltaic Specialists Conference, Washington DC, 1275-1278. https://doi.org/10.1109/PVSC.1996.564365

[19] Riesen, Y., Stuckelberger, M., Haug, F.-J., Ballif, C. and Wyrsch, N. (2016) Temperature Dependence of Hydrogenated Amorphous Silicon Solar Cell Performances. Journal of Applied Physics, 119, Article ID: 044505. https://doi.org/10.1063/1.4940392

[20] Arjyadhara, P., Ali, S.M. and Chitralekha, J. (2013) Analysis of Solar PV Cell Performance with Changing Irradiance and Temperature. International Journal of Engineering and Computer Science, 2, 214 